\title{
Production Scenarios of Mango (Mangifera indica L.) in Harari Regional State, Eastern Ethiopia
}

\author{
Tewodros Bezu^, Kebede Woldetsadik and Tamado Tana
}

\author{
School of Plant Sciences, College of Agriculture and Environmental Sciences, Haramaya University,
}

P. O. Box: 138, Dire Dawa, Ethiopia.

\begin{abstract}
Mango production covers $35 \%$ of the total acreage allotted for fruit production in Harari Regional State, eastern Ethiopia. However, there is a declining trend in yield and quality of fruits from the trees. Therefore, this study was conducted to assess the status, practices and challenges of mango production in the study area. Interviews were made taking 70 mango growers selected purposively in the major mango growing areas of the region using semi-structured questionnaire from 2012 to 2013. The results indicated that $50 \%$ of the households have few mango trees, 10-20 trees that are from seedling in origin derived from very few trees that were introduced from abroad via missionaries and traders a century ago. As a result, wide variations were observed in phenotypic features of trees within a farm as well as throughout the study area. In total, 39 distinct eco-types were recorded. Input shortage (water, fertilizer and pesticide), lack of improved technologies, pests (especially fruit fly and anthracnose), postharvest loss and poor marketing were the major problems specified by the growers. Therefore, focus should be given in improving the production, productivity and marketing of the crop in order to utilize the available and adaptable mango eco-types which are on the verge of disappearance.
\end{abstract}

Copyright@2014 STAR Journal. All Rights Reserved.

\author{
Article Information \\ Article History: \\ Received : 15-10-2014 \\ Revised : 18-12-2014 \\ Accepted : 29-12-2014 \\ Keywords: \\ Mango production Hararghe \\ Eco-types \\ Haramaya
}

*Corresponding Author:

Tewodros Bezu

E-mail:

tedrosneguse@yahoo.co.uk

\section{INTRODUCTION}

Fruit crops play an important role in the national food security of people around the world. They are generally delicious and highly nutritious, mainly of vitamins and minerals that can balance cereal-based diets. Fruits supply raw materials for local industries and could be sources of foreign currency. Moreover, the development of fruit industry will create employment opportunities, particularly for farming communities. In general, Ethiopia has great potential and encouraging policy to expand fruit production for fresh market and processing both for domestic and export markets. Besides, fruit crops are friendly to nature, sustain the environment, provide shade, and can easily be incorporated in any agro-forestry programs (MoARD, 2009).

The mango, because of its attractive appearance and the very pleasant taste of selected cultivars, is claimed to be the most important fruit of the tropics and has been touted as 'king of all fruits'. The fruit contains almost all the known vitamins and many essential minerals. The protein content is generally a little higher than that of other fruits except the avocado. Mangos are also a fairly good source of thiamine and niacin and contain some calcium and iron (Griesbach, 2003).

According to CSA (2012/2013), about 61,972.6 hectares of land is under fruit crops in Ethiopia; mangoes contributed $14.2 \%$ of the area. Moreover, out of 479,336 tons of fruits produced in the country, mangoes accounted $14.5 \%$ fruit production.

In Ethiopia, mango is produced mainly in Harari region, west and east Oromia, Southern Nations, Nationalities, and People's Region (SNNPR) and Amhara (Dendana et al., 2005). Wiersinga and Jager (2007) stated that, Eastern Ethiopia (Dire Dawa and Harar areas) is well-known for production and supply of both fruits and vegetables and about $35 \%$ of the total acreage allotted for fruit production is covered by Mango (Unpublished Haramaya University Horticulture Department Survey, 1996). Ishot (2009) stated the area covered by fruit crops in Harari People National Regional State by the year $2004 / 2005$ was about 163 ha owned by a total of 5,171 peasant holders altogether produced 30 ton. Out of this, the area occupied by mango was 115 ha. In Harari region, mango is grown dominantly in the central and lower parts of the Bisidimo and Erer River basins including in the vicinities of the Harar city.

A comparative study made between income from fruit growing and cereals (sorghum and maize) in Harar by TAM Agribusiness (2004) revealed that the annual income from fruit growing such as mango and custard apple was ETB 60,000/ha/yr compared to 2,000 for maize and only 1,000 for sorghum. Even if the farmer's livelihood is highly supplemented by the income from their mango trees, 
Tewodros Bezu et alo,

there is a declining trend in yield and quality of the fruits from the trees. Some of the factors contributing to this include foliar diseases, old age, poor management and variability of the trees (Yeshitela and Nessel, 2003). Except the farmers' traditional naming for identification, the trees are mixed and difficult for identification. To this end, this research was initiated with the objectives of assessing the sources and naming of ecotypes, status and constraints of mango production in Harari regional state and its surroundings.

\section{MATERIALS AND METHODS}

\section{Description of the Study Area}

The study was conducted on the major mangoproducing rural kebeles of Harari People's Regional State, specifically: Errer-Weldia (seven sub-kebeles: ErrerMarko, Gola-Ganda-Wedia, Itisa-Bakere, Itisa-GoroMaskida, Kona and Melka-Hida-Gedi), Harewe (four subkebeles: Agemboy, Bereser, Harewe-Kalu and Nole) and Bisidimo (Bisidimo leprosy referral hospital farm). The region is located in the eastern part of Ethiopia. The total geographical area is about $343.21 \mathrm{~km}^{2}$ and located between $42^{\circ} 03^{\prime}-42^{\circ} 16^{\prime} \mathrm{N}$ and $9^{\circ} 11^{\prime}-9^{\circ} 24^{\prime} \mathrm{E}$.

Administratively, the region is divided in six urban and three rural weredas (districts). These administrative weredas are further divided into 19 and 17 kebeles in urban and rural, respectively. The region is mainly categorized in two agro-ecological zones, i.e. 90\% of the land area of the region is mid-high land (weynadega), between $1400-2200$ meter above sea level, while the remaining $10 \%$ is lowland or kola $(<1500$ meter above sea level) (Sultan et al., 2011).

The climate of the region is suitable for production of diverse horticultural crops where temperature is ranging between $17.1^{\circ} \mathrm{C}-20.2^{\circ} \mathrm{C}$ throughout the year. The coolest season is between June and September and coincides with main rains. The average annual amount of precipitation is about 750-1,000 $\mathrm{mm}$ (http://hararconnection.com/hnrs.htm).

\section{Sampling Methods, Data Collection and Analysis}

The study areas were selected based on their potential of mango production. Total respondent of the survey were 70 growers selected purposively based on their experience in mango production. Both primary and secondary data were used to obtain the required information for the study. Accordingly, the primary data were collected using semi structured questionnaire and personal observation. And the secondary data were collected from different sources (reports, wereda agriculture offices and developmental agents).

The data collected were summarized and percentages, frequency distribution and arithmetic means were calculated using SPSS version 17.

\section{RESULTS AND DISCUSSION}

Mango Eco-types and Management Practices in Harari Regional State, Eastern Ethiopia

The mango ecotypes recorded were diverse across locations and farmers (Table 1). In total, 39 eco-types were recorded. The prefixes of all ecotypes in the study area were the same 'Amba' meaning 'Fruit' in Afan Oromo language. However, naming after prefix were different and
Sci. Technol. Arts Res. J., Oct-Dec 2014, 3(4): 59-63

indicate the fruit characters (appearance, taste, shape, texture, color, fiber content and aroma) and the sources of the seed or names of the person introduced into the area or owing distinct types. The different names for mango around the world today also reflect the cultures and languages spoken by people who grow them. Many of the names have common derivations, reflecting the origins and spread of the mango tree along with the spread and settlement of communities (Bally, 2006). Due to traditional naming for identification, the trees are mixed and difficult for identification. As a result, there could be two or more name for same cultivar or different types given one name (Yeshitela and Nessel, 2003). This scenario is in accord to Sennhenn et al. (2014) who stated the large number of local languages in Kenya lead to confusion about clear identification of mango landraces as many different names existed for the same landrace.

The number of trees per household varies from 10-50, depending on size of the farm land and preference of farmers (Table 2). However, the majority $(71 \%)$ of growers have less than 20 trees while few $(6 \%)$ of respondents have more than 40 trees. Similar holdings by peasant growers have also been reported by Ssemwanga et al. (2008) in Assosa (western Ethiopia) and Seid and Zeru (2013) in Bati (northern Ethiopia). As indicated in Table 2, the entire mango trees in the study area were established from seeds. This could be the reason for the existing variability in the nature of the trees (Bally, 2006).

Regarding the sources of the existing trees, $22 \%$ of respondents indicated that their seeds were introduced from Saudi Arabia by Muslims who used to go to Mecca and probably from other countries by traders and missionaries. However, none of the respondents were able to tell names of original cultivars. From those introduced varieties that the majorities of existing trees $(77 \%)$ were multiplied by the growers. Furthermore, except few growers (5.7\%) who used supplemental irrigation from their bore hole, more than $90 \%$ of the respondents were dependent on rainfall.

While majority of the trees are old, only few growers have recently started planting mango. Attempt was made to assess age of the mango trees, but, almost all of the farmers responded that they did't know the exact age of their trees rather they estimated them to be more than 80 years old. This appears to hold true as mango tree is long-lived with some specimens known to be over 150 years old and still producing fruit (Griesbach, 2003).

\section{Management Practices}

Nearly the entire mango ecotypes observed were planted without any pattern and recommended spacing and also pruning of the trees was not practiced (Table 3). Due to this fact, the trees were too crowded, very tall and the undersides of the canopy of the trees were without leaves and fruits. Overcrowding results in the production of fewer fruits which are apt to be poorly colored and infected with diseases. Tall trees also present a harvesting problem and create difficulties during spraying and pruning (Griesbach, 2003). In general, well managed orchard trees require regular annual pruning to maintain an open canopy of manageable size. This allows air and sunlight to penetrate, which reduces pests and diseases and enhances fruit color (Bally, 2006). 
Table 1: Identification of mango ecotypes in Harari Regional State, Eastern Ethiopia

\begin{tabular}{|c|c|c|c|}
\hline No. & Local Name & Meaning & Kebele* $^{*}$ \\
\hline 1 & Amba Adi & Describing flush color & EW \\
\hline 2 & Amba Adi Ako & Describing flush color and introduced person & EW \\
\hline 3 & Amba Ako & Describing introduced person & EW \\
\hline 4 & Amba Alege & Describing fiber content of fruit & $\mathrm{EW}$ and $\mathrm{H}$ \\
\hline 5 & Amba Ali Dula & Describing introduced person & $\mathrm{EW}$ \\
\hline 6 & Amba Arenchata & Describing texture and taste of fruit & EW \\
\hline 7 & Amba Babala & Describing shape of fruit & $\mathrm{EW}, \mathrm{H}$ and $\mathrm{B}$ \\
\hline 8 & Amba Bare & Describing introduced person & $\mathrm{EW}$ and $\mathrm{H}$ \\
\hline 9 & Amba Bishanoo & Describing taste and juiciness of fruit & $\mathrm{EW}$ and $\mathrm{H}$ \\
\hline 10 & Amba Dera & Describing size of fruit & EW \\
\hline 11 & Amba Dinche & Describing shape of fruit & EW \\
\hline 12 & Amba Doke & Refers to origin & EW \\
\hline 13 & Amba Dula & Describing introduced person & $\mathrm{EW}$ and $\mathrm{H}$ \\
\hline 14 & Amba Errero & Refers to origin & $\mathrm{H}$ \\
\hline 15 & Amba Forfor & Describing texture and taste of fruit & $\mathrm{H}$ \\
\hline 16 & Amba Geratune & Refers to origin & $\mathrm{H}$ \\
\hline 17 & Amba Gerjewi & Describes taste & $\mathrm{H}$ \\
\hline 18 & Amba Guracha & Describing color of fruit skin & $\mathrm{EW}, \mathrm{H}$ and $\mathrm{B}$ \\
\hline 19 & Amba Guracha Gola & Describing color of fruit skin and origin & $\mathrm{EW}$ \\
\hline 20 & Amba Harewe & Refers to origin & $\mathrm{EW}$ and $\mathrm{H}$ \\
\hline 21 & Amba Huda & Describing productivity of tree & $\mathrm{EW}$ and $\mathrm{H}$ \\
\hline 22 & Amba Hula & Refers to origin & $\mathrm{EW}$ \\
\hline 23 & Amba Kawe & Describing shape of fruit & $\mathrm{EW}$ and $\mathrm{H}$ \\
\hline 24 & Amba Kukurfa & Describing shape of fruit & $\mathrm{EW}$ \\
\hline 25 & Amba Lafe & Describing size seed & $\mathrm{EW}$ and $\mathrm{H}$ \\
\hline 26 & Amba Libanatoo & Describing pulp aroma & $\mathrm{H}$ \\
\hline 27 & Amba Lilo & Describing introduced person & EW \\
\hline 28 & Amba Meriyo & Describes fruit appearance & $\mathrm{H}$ \\
\hline 29 & Amba Mucho & Describes fruit shape & $\mathrm{EW}$ and $\mathrm{H}$ \\
\hline 30 & Amba Mujulo & Describing size & $\mathrm{H}$ \\
\hline 31 & Amba Negus & Describing fruit size & $\mathrm{EW}, \mathrm{H}$ and $\mathrm{B}$ \\
\hline 32 & Amba Sabune & Describing color and texture of fruit & EW \\
\hline 33 & Amba Saburugena & Refers to origin & $\mathrm{H}$ \\
\hline 34 & Amba Sadiko & Describing introduced person & EW \\
\hline 35 & Amba Shimbiro & Describing taste of fruit & EW \\
\hline 36 & Amba Sibake & Describing taste of fruit & EW \\
\hline 37 & Amba Teyara & Describing fruit shape & $\mathrm{EW}$ and $\mathrm{H}$ \\
\hline 38 & Amba Umer Alisho & Describing introduced person & EW \\
\hline 39 & Amba Umer Aso & Describing introduced person & EW \\
\hline
\end{tabular}
${ }^{\star}$ EW: Errer Weldia, $\mathrm{H}$ : Harewe and B: Bisidimo

Table 2: Mango production status in Harari Regional State, Eastern Ethiopia

\begin{tabular}{lcc}
\hline Variable & $\begin{array}{c}\text { Number of } \\
\text { respondents }\end{array}$ & $\%$ \\
\hline Number of trees per household & & \\
$<20$ & 50 & 71.4 \\
$21-30$ & 10 & 14.3 \\
$31-40$ & 6 & 8.6 \\
$>40$ & 4 & 5.7 \\
Type of planting material & & \\
Seedling & 70 & 100 \\
Grafted & 0 & 0 \\
Source of planting material & & \\
Local & 54 & 77.1 \\
Imported & 16 & 22.7 \\
Water source & & \\
Rain & 66 & 94.3 \\
Bore hole & 4 & 5.7 \\
& & \\
\hline
\end{tabular}


Table 3: Management practices of mango trees in Harari Regional State, Eastern Ethiopia

\begin{tabular}{lcc}
\hline \multicolumn{1}{c}{ Variable } & $\begin{array}{c}\text { Number of } \\
\text { respondents }\end{array}$ & $\%$ \\
\hline Plant spacing & 3 & 4.3 \\
Recommended $(7 \mathrm{~m} \times 7 \mathrm{~m})$ & 67 & 95.7 \\
Not recommended & 19 & 27.1 \\
Pruning & 51 & 72.9 \\
Yes & & \\
No & 18 & 25.7 \\
Fertilizer application & 3 & 4.3 \\
Organic & 49 & 70 \\
Inorganic* & & \\
None & 0 & 0 \\
Pest management practices & 70 & 100 \\
Pesticide & 0 & 0 \\
Cultural (smoking, cleaning etc.) & Integrated & \multicolumn{2}{c}{. } \\
(Di-ammonium phosphate) and Urea but unknown rates of application
\end{tabular}

Nearly $70 \%$ of the growers did not supplement their trees with any form of fertilizer but some (26\%) use organic fertilizers such as compost and manure. However, the rates of fertilizer required for mango trees have not yet been standardized for the study area. Mango trees are usually left unfertilized once established. This is in accord with the study by Seid and Zeru (2013) who reported that $90 \%$ of growers in northern Ethiopia did not apply neither inorganic nor organic fertilizer on their farmland.

Regarding pests and their management, the respondents pointed out that the major insect pests were fruit fly $(100 \%)$, thrips $(21 \%)$ and termites $(10 \%)$ while diseases included powdery mildew $(99 \%)$ and anthracnose (100\%) (Table 4). Both diseases are known to be most common during wet weather in Ethiopia (Giuseppe De Bac, 2010). For the management of the aforementioned pests, cultural practices like smoking are used especially during flowering and sanitation measures via removing diseased branches and weeding (Table 3) due to several factors such as unavailability of pesticide, technical problems in spraying tall trees and economical issues (Table 5).

Moreover, postharvest handling problems were observed in the study area. About $91 \%$ of the growers transport their produce in synthetic fiber sacks while very few $(8 \%)$ use wooden box and transport to the market by animals like donkey, car and by the farmers themselves to the nearby village market. Plastic crates, which are stackable, stable, easy to clean and reuse has been shown to reduce damage of perishable crops from an average of $30 \%$ to less than $10 \%$ (Kitnoja, 2010). Hence, the postharvest constraints mentioned by the respondents could be alleviated by demonstrating and promoting use of plastic crates with appropriate transportation methods.

\section{Mango Production Constraints}

The major production constraints indicated by the respondents in the study area were water shortage or erratic rainfall $(79 \%)$ followed by pest $(75.7 \%)$ problems (Table 6). Lack of knowledge and recommended production practices (nutrition, pruning, pest management etc.) and post-harvest losses were also noted as major problems of the growers. It is in agreement with CSA (2009) report that stated mango production in Ethiopia fluctuates because of occurrence of diseases and lack of proper management (CSA, 2009) and IPMS (2011) report indicated in addition to the lack of improved varieties, the development of fruit production was severely hampered by lack of knowledge and skills, in particular on the production of grafted seedlings pilot learning woredas in north and southwest of Ethiopia.

Likewise, absence of good marketing system that could benefit or attract the growers is the additional bottleneck raised (Table 6). As a result, the growers reflected their tendency towards cultivation of other cash crops like khat (Catha edulis) by uprooting the exiting trees. The tendency to shift to other cash generating crops is also most common in other parts of the country (Semwanga et al., 2008; Seid and Zeru, 2013).

Table 4: Major pests of mango in Harari Regional State, Eastern Ethiopia

\begin{tabular}{lcl}
\hline Variable & Number of respondents & $\%$ \\
\hline Insect pest & 15 & \\
Thrips & 70 & 21.4 \\
Fruit fly & 7 & 100 \\
Termite & & 10 \\
Diseases & 69 & \\
Powdery mildew & 70 & 98.6 \\
Anthracnose & 2 & 100 \\
Others & 2.9 \\
\hline
\end{tabular}

Table 5: Mango postharvest packaging materials and transportation systems used in Harari Regional State, Eastern Ethiopia

\begin{tabular}{lcl}
\hline Variable & Number of respondents & $\%$ \\
\hline Materials for packing & & \\
Plastic sack & 64.00 & 91.4 \\
Wooden box & 6.00 & 8.6 \\
Transportation means & & \\
Human & 15.00 & 21.4 \\
Animals & 29.00 & 41.4 \\
Car & 26.00 & 37.1 \\
\hline
\end{tabular}

Table 6: Summarized production constraints of mango in the Harari Regional State, Eastern Ethiopia

\begin{tabular}{lcc}
\hline \multicolumn{1}{c}{ Constraints } & $\begin{array}{c}\text { Number of } \\
\text { respondents }\end{array}$ & $\%$ \\
\hline Erratic rainfall (scarcity of irrigation water) & 55 & 79.0 \\
Insect pests and diseases & 53 & 75.7 \\
Lack of knowledge and skill & 44 & 62.9 \\
Postharvest fruit rot & 35 & 50.0 \\
Flowers and fruit drop & 30 & 42.9 \\
Shortage of fertilizer & 15 & 21.4 \\
Poor marketing & 9 & 12.9 \\
\hline
\end{tabular}




\section{CONCLUSIONS}

Mango production has a long history in eastern Ethiopia particularly in eastern Hararghe. There is remarkable variability among the existing mango trees and fruits since almost all growers propagate it sexually even though other variables like ecological, edaphic factors and crop husbandry practices could contribute to the variation. The study revealed the potentials of mango production but demands serious attention to the existing trees with regard to promotion of potential germplasm by grafting propagation method and use of appropriate husbandry practices. Moreover, maintaining as many mango varieties as possible is necessary as a basis for breeding activities, which allows the development of better adapted and pest/disease-tolerant varieties with a high value for domestic and export markets. Focus should be given in improving the production, productivity and marketing of the crop in order to utilize the available and adaptable mango eco-types which are on the verge of disappearance.

\section{ACKNOWLEDGEMENT}

We thank Haramaya University for the financial support of the study, Harari regional state agriculture office and experts as well as mango growers in the region for kind collaboration during the study. Moreover, we are grateful to laboratory and field technicians of the horticulture program, for their unreserved assistance during the research work.

\section{REFERENCES}

Bally, I.S.E. (2006). Mangifera indica (mango), ver. 3.1. In: Elevitch, C.R. (ed.). Species Profiles for Pacific Island Agro-forestry. Permanent Agriculture Resources (PAR), Hōlualoa, Hawai'i. [Available online: http://www.agroforestry.org/images/pdfs/Mangiferamango.pdf. Accessed 23 August 2014].

CSA (Central Statistical Agency). (2009). Agricultural sample survey: report on area and production for major crops, stastical bulletin 427. Addis Ababa, Ethiopia.

CSA (Central Statistical Agency). (2013). Area and production of major crops. Addis Ababa, Ethiopia.

Dendana, C., Desta, H. and Alfons, D. (2005). Export potential of Ethiopia processed fruit and vegetables. [Available online: http://www.eap.gov.et/sites/defaul t/files/EAPortal/Agricultural\%20Commodities/Crops/Fr uit\%20Crops/Tropical/juicy\%20fruit\%203.pdf. Accessed 30 May 2014].

Griesbach, J. (2003). Mango growing in Kenya. World Agro forestry Centre (ICRAF). Nairobi, Kenya.

Giuseppe De Bac. (2010). Technical guidelines on tropical fruit tree management in Ethiopia. [Available online: http://www.fao.org/docrep/field/009/an474e/an474e00. pdf. Accessed 01 May 2014].

Harar Vision Net. (2010). Harari profile. [Available online: http://www.hararvisionnet.org.et/Harari\%20Profile.html Accessed 30 May 2014].

Joosten, F. (2007). Development strategy for the Exportoriented horticulture in Ethiopia. Wageningen, Netherlands. pp.52.

IPGRI (International Plant Genetic Resources Institute). (2006). Descriptors for Mango (Mangifera indica L.). Rome, Italy.
IPMS (Improving Productivity and Market Success). (2011). Fruits-A synthesis of IPMS value-chain development experiences.[Available online: http://www.ipms-ethiopia.org/content/files/Documents/ publications/Commodity\%20Case\%20Studies/Fruits_s ynthesis.pdf. Accessed 04 October 2014].

Ishot. (2009). Study of regional potential resources. Volume 1, Issue 1.HarariStates' Office of the President Diaspora Office, Harar. [Available online: http://hararconnection.ethionetlink.com/ISHOT-NO\%2001.pdf Accessed 08 October 2014].

Kitnoja, L. (2010). Identification of appropriate postharvest technologies for improving market access and incomes for small horticultural farmers in Sub-saharan Africa and South Asia. WFLO grant final report to the Bill and Melinda Gates Foundation. Pp. 3-8.

MoARD (Ministry of Agriculture and Rural Development). (2009). Improved technologies and resource management for Ethiopian agriculture. A Training Manual. RCBP-MoARD, Addis Ababa, Ethiopia.

MoARD (Ministry of Agriculture and Rural Development). (2005). Vegetables and fruits production and marketing plan (Amharic Version), MoARD, Addis Ababa, Ethiopia.

Seid Hussen and Zeru Yimer. (2013). Assessment of production potentials and constraints of mango (Mangifera indica L.) at Bati, Oromia zone, Ethiopia. International Journal of Sciences: Basic and Applied Research 11(1):1-9.

Seifu Gebre-Mariam. (2003). Status of commercial fruit production in Ethiopia. Ethiopian Agricultural Research Institute (EIAR), pp. 91.

Semwanga, J., Rowlands, C. and Joseph, K.K. (2008). Analysis of the mango value chain from HomoshaAssosa to Addis Ababa. [Available online: http://www.value-chains.org/dyn/bds/docs/774/ mangoesethiopia. pdf. Accessed 01 June 2014].

Sennhenn, A., Prinz, K., Gebauer, J., Whitbread, A., Jamnadass, R., Kehlenbeck, K. (2014). Identification of mango (Mangifera indica L.) landraces from Eastern and Central Kenya using a morphological and molecular approach. Genet Resour Crop Evol 61:722.

Sultan, H., Radi, A., Hana, A., Kalid, A., Fethi, A., Tesfaye, N. and Adib, A. (2011). Harari people regional state program of plan on adaption to climate change. [Online:http://www.epa.gov.et/Download/Clim ate/Regional\%20Climate\%20Change\%20Adaptation\% 20Programmes/Harri\%20Regional\%20State\%20Clima te\%20Change\%20Adaptation\%20Program.pdf.

TAM Agribusiness. (2004). Fruit production in agroforestry systems in Bonga. A Private Rural Development\& Agricultural Extension Agency. A Public-Private-Rural Community partnership, March 2004, Addis Ababa.

Wiersinga, R. and Jager, A. (2007). Identification of opportunities and setting agenda of activities in the Ethiopian fruits and vegetables sector, Mission Report, Ethiopian-Netherlands Horticulture Partnership.

Yeshitila, T. and Nessel, T. (2003). Characterization and classification of mango ecotypes grown in eastern hararghe (Ethiopia). Sarhad Journal of Agriculture 19(2):1-2. 